\title{
ASSESSMENT OF SENSITIVITY OFPUSHOVER ANALYSIS
}

\author{
Sripad.D.B ${ }^{1}$, Poornachandra Pandit ${ }^{2}$ \\ ${ }^{1}$ Post Graduate student, Civil Engineering, M.I.T, Manipal University, Manipal, Karnataka, India \\ ${ }^{2}$ Assistant Professor, Civil Engineering, M.I.T, Manipal University, Manipal, Karnataka, India \\ dbs.51091@gmail.com,pc.pandit@manipal.edu
}

\begin{abstract}
In this present study, an attempt has been made to determine the uncertainty occurring in pushover analysis results for a Reinforced Concrete $(R C) G+2$ storied frame modeled as a bare frame and frame with rigid diaphragm slab by considering userdefined hinges using non-linear static pushover analysis using SAP2000. Since the output of the analysis is very much sensitive and susceptible to design parameters, to interpret the sensitivity analysis by varying the strength of steel, concrete and hinge lengthon the performance of structures and compare the variation in the performance which is randomly generated and incorporated into the analysis. The nonlinear behavior of the elements wasmodeled using plastic hinges based on the momentcurvature relationship as described in Federal Emergency Management Agency (FEMA)-356 and Applied Technology Council (ATC)-40. A seismic response like base shear, roof displacement corresponding to performance point was evaluated using nonlinear static analysis. The experimental results were compared with analytical results.
\end{abstract}

Keywords: Non-Linear Static Pushover Analysis, Lateral Load, Concrete and Cover, Moment-Curvature Analysis, Hinge Length.

\section{INTRODUCTION}

The intent of Pushover analysis is to assess the expected performance by analysing its strength and deformation requirements in the seismic design of structure by using Non-linear static analysis and evaluating these requirements to accessible capacities at important performance levels. The utilization of non-linear study is vital to represent the performance of buildings under earthquake action as observed by Mehmet Inel and Ozmen (2006) [2]. In past, many types of research works have been achieved on traditional non-linear analysis and after inspecting flaws, attempts have been developed to better the results. Ashraf Habibullah et al (1998) [1] suggested the practical steps used to perform the pushover analysis in SAP2000 software. It documents the approach for modeling and defining the criteria for a hinge as per ATC-40 and FEMA documents. Krawinkler and Seneveritna (1998) [6] conferred about advantages and disadvantages of the Pushover analysis. They assessed the accuracy of the method and recognized the cases in which the pushoverpredictions areunreliable.

Much improvisation is required, combined with experimentally obtained results and analysis stressed by S.Elnashai (2001) [7]. But the experimental test results are rarely available to correlate with pushover analysis. In the present study, the analytical results are being correlated with experiment results which were conducted in Structural Engineering Research Center (SERC), Chennai.

\section{EXPERIMENTAL SPECIFICATIONS}

The experiment test as shown in figure. 1 was performed by Akanshu Sharma at SERC, Chennai. Servo-hydraulic actuators was used to propel the RC frame to take reaction. The load distribution was parabolic along the height. The experiment was conducted governed by increasing monotonic pushover loads with the load distribution being parabolic along the height of the structure. The maximum base shear was $286.5 \mathrm{kN}$ and corresponding roof displacement was $0.110 \mathrm{~m}$.

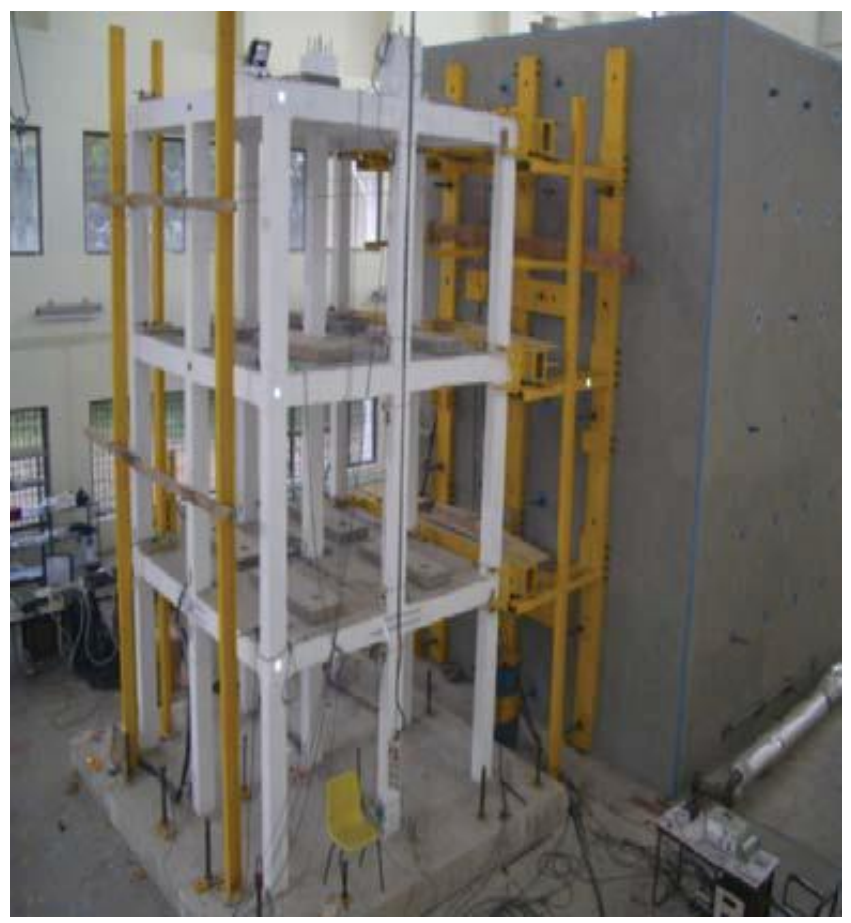

Fig-1: Experimental System for Pushover Test

In this paper, keeping the basis of experimentally obtained results of corresponding base shear and roof displacement, the frame structure is modeled in SAP 2000 program and analyzed to inspect the sensitivity of pushover curve. 


\section{DESCRIPTION OF THE STRUCTURE}

\subsection{Sectional Details}

The structure is G+2 storeyed RC framed structure. Fig.1 shows actual test structure.

Column dimension- $150 \mathrm{~mm} \times 200 \mathrm{~mm}$

Beam dimension- $150 \mathrm{~mm} \times 200 \mathrm{~mm}$

Reinforcement- Beam - 2-12 $\Phi$ at top

2-16 $\Phi$ at bottom

Column-2-16 $\Phi$ at top

\section{2-16 $\Phi$ at bottom}

Stirrups-6 $\Phi @ 150 \mathrm{~mm}$ c/c for beams and

column

Slab thickness- $50 \mathrm{~mm}$

The average concrete strength of the tested structure- $35 \mathrm{Mpa}$ The average reinforcement yield stress of the tested structure $-478 \mathrm{Mpa}$

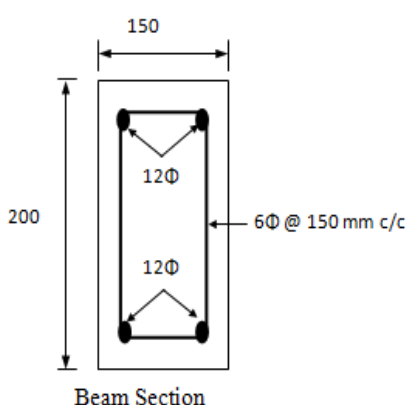

Fig-2: Sectional Properties of Beam and Column

\subsection{Modelling Details}

Material and geometrical properties are assigned as per the experimental structure and a basic model is generated in SAP2000. Different inbuilt default and user defined plastic hinge options are available in SAP2000 based on average values from ATC-40 [6] and FEMA-273 [8] for concrete members and steel members respectively. As the userdefined hinges reflect elemental nonlinearity behaviour, user-defined hinges are preferred over default hinge options. To use user-defined hinge properties selection momentcurvature analysis of each element is required. Momentcurvature values are generatedbased on a material model for concrete and steel. In the present study, IS suggestedstressstrain model for unconfined concrete and British code (CP110-1972) for steel have been adopted as shown in figure 3 and figure 4 . The generated values of moment-curvature of beam and column are shown in table 1 and table 2. Moment values are in $\mathrm{kN}-\mathrm{m}$.

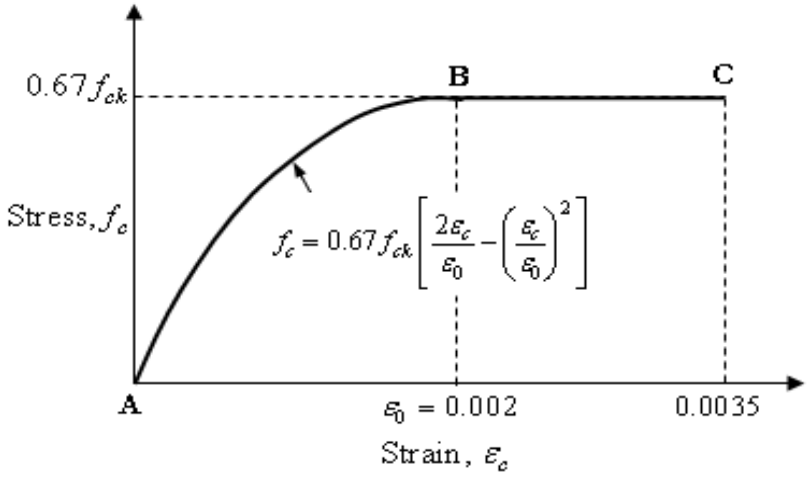

Fig-3: IS suggestedstress-strain model for unconfined concrete

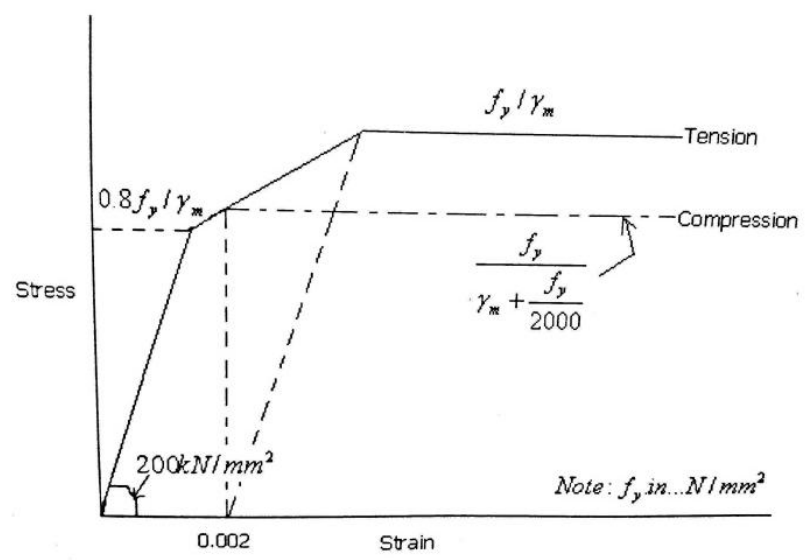

Fig-4: Stress-straincurve for steel suggested by British code

\subsection{Load Calculations}

After modeling the structure, pushover load cases are defined. Generally, after applying gravity load as the first pushover load case, then following lateral pushover load is applied to start from the final state of gravity loading. Structures along the height of the structure are subjected tolateral loads, which are based on the formula in Eq. (1), in FEMA 356 [4], shown below and then incorporated in the model.

$$
\begin{aligned}
\text { - } & F x=\frac{W x h x^{k}}{\sum_{i=1}^{N} W i h i^{k}} V \\
\text { - } \quad C_{v x} & =\frac{W x h x^{k}}{\sum_{i=1}^{N} W i h i^{k}}
\end{aligned}
$$

Where $F x$ is lateral load applied at any floor level " $\mathrm{x}$ ", $\mathrm{W}$ is total building weight, $\mathrm{h}$ is the floor height, $\mathrm{V}$ is lateralloadand $\mathrm{N}$ is the number of floors. Cvxis vertical distribution

Table-1:Moment-curvature data for beams

\begin{tabular}{|c|c|c|c|c|c|}
\hline \multirow{2}{*}{ Points } & A & B & C & D & E \\
\cline { 2 - 6 } & Origin & Yielding & Ultimate & $\begin{array}{c}\text { Strain- } \\
\text { hardening }\end{array}$ & $\begin{array}{c}\text { Strain- } \\
\text { hardening }\end{array}$ \\
\hline fy $=478 \mathrm{~N} / \mathrm{mm}^{2}$ & $\mathrm{M}=0$ & $\mathrm{M}=13.8$ & $\mathrm{M}=14.04$ & $\mathrm{M}=14.82$ & $\mathrm{M}=16.9$ \\
$\mathrm{fck}=35 \mathrm{~N} / \mathrm{mm}^{2}$ & $\Phi=0$ & $\Phi=0.0126$ & $\Phi=0.0748$ & $\Phi=0.0801$ & $\Phi=0.0951$ \\
\hline
\end{tabular}


Table-2: Moment-curvature data for columns

\begin{tabular}{|c|c|c|c|c|c|}
\hline \multirow{2}{*}{ Points } & A & B & C & D & E \\
\cline { 2 - 6 } & Origin & Yielding & Ultimate & $\begin{array}{c}\text { Strain- } \\
\text { hardening }\end{array}$ & $\begin{array}{c}\text { Strain- } \\
\text { hardening }\end{array}$ \\
\hline & $\mathrm{M}=0$ & $\mathrm{M}=23.0$ & $\mathrm{M}=23.9$ & $\mathrm{M}=24.92$ & $\mathrm{M}=27.79$ \\
$\mathrm{fy}=478 \mathrm{~N} / \mathrm{mm}^{2}$ & $\Phi=0$ & $\Phi=0.0148$ & $\Phi=0.0915$ & $\Phi=0.098$ & $\Phi=0.1183$ \\
$\mathrm{fck}=35 \mathrm{~N} / \mathrm{mm}^{2}$ & & & & & \\
\hline
\end{tabular}

factor for the lateral load. Using the above equation, the lateral loads were calculated. The lateral loads were applied in the ratio of 9:4:1on each floor as generated by above equation and then applied to the model.

\section{ANALYSIS AND RESULTS}

The preliminary analysis was performed by taking into the account of the material properties which were used in experiment and considering bare frame and rigid diaphragm slab was done in SAP2000. From the analysis performed, it was observed that for the bare frame model the base shear
(P) andcorresponding displacement $(\Delta)$ was found to be $167 \mathrm{kN}$ and $0.268 \mathrm{~m}$ respectively and for rigid diaphragm slab, the base shear $(\mathrm{P})$ and corresponding displacement $(\Delta)$ was found to be $276 \mathrm{kN}$ and $0.172 \mathrm{~m}$ respectively. Thus, from the analysis results obtained, it is evident that the experiment results vary to analysis results. Hence, from the obtained results, the pushover analysis for material and geometric modeling are sensitive and susceptible. The percentage differenceof base shear and displacement is shown in table. 3 .

Table-3: Percentage difference of base shear and displacement

\begin{tabular}{|c|c|c|c|c|}
\hline Frame & Base Shear $(\mathrm{kN})$ & $\begin{array}{c}\text { Percentage less than } \\
\text { experiment }\end{array}$ & Displacement $(\mathrm{m})$ & $\begin{array}{c}\text { Percentage more } \\
\text { than experiment }\end{array}$ \\
\hline Bare Frame & 167 & $41.7 \%$ & 0.268 & $143.6 \%$ \\
\hline $\begin{array}{c}\text { Rigid Diaphragm } \\
\text { slab }\end{array}$ & 276 & $3.6 \%$ & 0.172 & $56.3 \%$ \\
\hline
\end{tabular}

The plastic hinge length is an important design parameter where extreme confinement should be provided to increase the ductility of the member for the extremeseismicaction. Further investigation is carried out to check the possible variation in the results obtained from pushover analysis by adopting bare frame and rigid diaphragm slab model by calculating hinge length using different hinge length properties available in the literature by considering userdefined hinges.Various different formulations have been suggested for calculating the corresponding user-defined plastic hinge lengths $L_{p}$. The length of the user-defined hinge is considered from the following formulations,

1. Corley's formula

- $\mathrm{L}_{\mathrm{p}}=0.5 \mathrm{~d}+0.2 \sqrt{\mathrm{d}}\left(\frac{\mathrm{z}}{\mathrm{d}}\right)$

2. Park's formula

- $\mathrm{L}_{\mathrm{p}}=0.42 \mathrm{~h}$

3. Priestly-Park's formula

- $\mathrm{L}_{\mathrm{p}}=0.8 \mathrm{z}+6 \mathrm{~d}_{\mathrm{b}}$

4. Panagiotakos-Fardis's formula

- $\mathrm{L}_{\mathrm{p}}=0.18 \mathrm{z}+0.021 \mathrm{~d}_{\mathrm{b}} \mathrm{f}_{\mathrm{y}}$

5. Berry's formula
- $\mathrm{L}_{\mathrm{p}}=0.05 \mathrm{z}+\left(\frac{0.1 \mathrm{dbfy}}{\sqrt{\mathrm{fc}}}\right)$

Where,

$\mathrm{d}_{\mathrm{b}}=$ diameter of longitudinal reinforcing bars, in $\mathrm{mm}$

$\mathrm{f}_{\mathrm{y}}=$ yield stress of reinforcing bars, in $\mathrm{N} / \mathrm{mm}^{2}$

$\mathrm{z}=$ Critical section distance from the point of contra-

flexure, in $\mathrm{mm}$

$\mathrm{d}=$ effective depth of the cross section, in $\mathrm{mm}$

$\mathrm{h}=$ Overall depth of the cross section, in $\mathrm{mm}$

$\mathrm{f}_{\mathrm{c}}=$ compressive strength of concrete, in $\mathrm{N} / \mathrm{mm}^{2}$

Using above formulations by considering user-defined hinge option the bare frame andrigid diaphragm slab was analyzed. The pushover analysis resultsare shown in table. 4 and table.5 respectively. The comparative graphs of pushover curves for different hinge length are shown in figure. 5 and figure. 6 respectively. From the graph, base shear and displacement were not much varied but when different hinge length properties were considered, it was observed that there was a large difference in base shear and displacement. 
Table-4: Base Shear and Displacement Values for Bare frame

\begin{tabular}{|c|c|c|}
\hline Formulations & Base Shear $(\mathrm{kN})$ & Displacement $(\mathrm{m})$ \\
\hline Berry & 161.62 & 0.072 \\
\hline Corley & 163.06 & 0.093 \\
\hline Panagiotakos and Fardis & 161.27 & 0.065 \\
\hline Park & 161.18 & 0.060 \\
\hline Priestly and Park & 160.66 & 0.057 \\
\hline
\end{tabular}

Table-5: Base Shear and Displacement Values for Rigid Diaphragm slab

\begin{tabular}{|c|c|c|}
\hline Formulations & Base Shear $(\mathrm{kN})$ & Displacement $(\mathrm{m})$ \\
\hline Berry & 272.89 & 0.050 \\
\hline Corley & 273.89 & 0.051 \\
\hline Panagiotakos and Fardis & 272.50 & 0.045 \\
\hline Park & 271.15 & 0.033 \\
\hline Priestly and Park & 272.08 & 0.040 \\
\hline
\end{tabular}

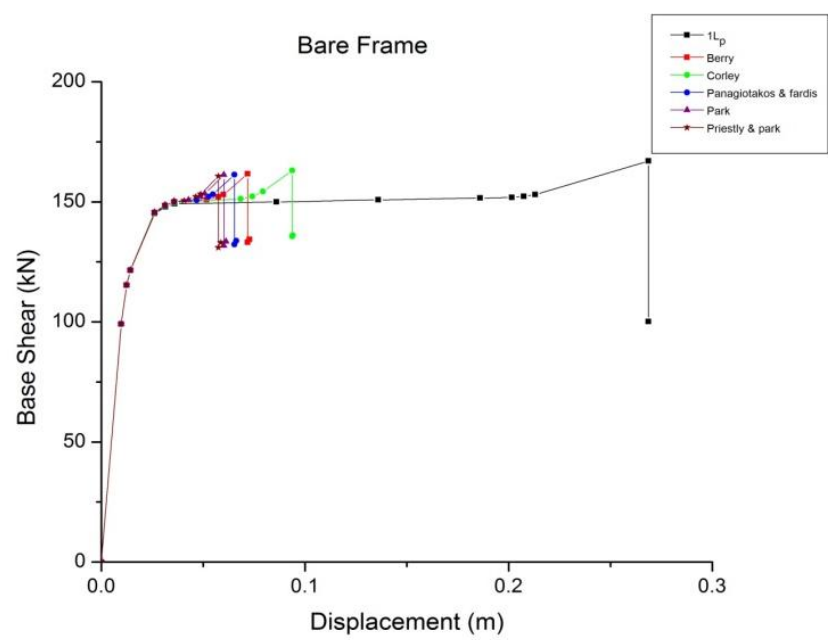

Fig-5: Comparison of Pushover curve for different hinge length (Bare frame)

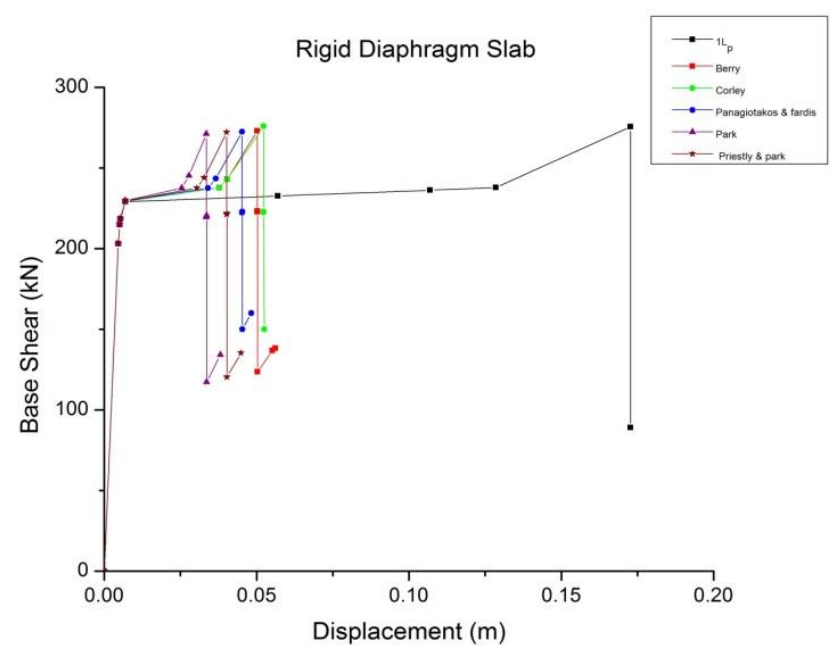

Fig-6: Comparison of Pushover curve for different hinge length (Rigid Diaphragm slab)

\section{CONCLUSION}

- In bare frame model, it was observed that values of Base Shear values were low, whereas values for displacement were high due to slab stiffness was not considered.

- For bare frame model, Base Shear variation was found to be $40-46 \%$ lesser than experiment values and Displacements about $15-48 \%$ less.

- For Rigid Diaphragm slab model, Base shear was found 4-5\% lesser than experiment values and Displacement about $53-70 \%$ less.

- For Bare frame model considering hinge length formulations, comparing with experiment values, both base shear and displacement values were less.

- For Rigid Diaphragm slab model considering hinge length formulations, comparing with experiment values, the base shear was nearer while displacement was less.

- Therefore, Non-linear static pushover analysis results are greatly sensitive and susceptible to changes made in geometrical modeling, material properties, hinge length properties etc and precise efficient analysis method is required to predict the experimental results with the analysis for more accurate results.

\section{ACKNOWLEDGEMENT}

I would take this opportunity as a privilege to thank my family and my respected guide Dr. PoornachandraPandit to their continuous guidance, inspiration and support, which are main factors behind any work. I take the pleasure of thanking all those who have helped, supported and gave constant encouragement throughout my work without whom, this work would not have been completed in time.

\section{REFERENCES}

[1]. Habibullah, A. and Pyle, S. "Practical threedimensional nonlinear static pushover Analysis”, Structure Magazine Berkley, CA. 1998. 
[2]. Inel M, Ozmen HB. "Effects of plastic hinge properties in nonlinear analysis of reinforced concrete buildings". EngStruct 2006; 28:1494-502.

[3]. ATC-40, "Applied Technology Council, Seismic evaluation and retrofit of concrete Buildings". California, 1996.

[4].FEMA-356, "Federal Emergency Management Agency, Pre-standard and commentary for seismic rehabilitation of buildings"; 2000.

[5].FEMA-273, "Federal Emergency Management Agency, NEHRP guideline for Seismic rehabilitation of buildings Washington (DC) "; 1997

[6]. Krawinkler H, Seneviratna. "Pros and cons of a pushover analysis of seismic performance evaluation". J EngStruct 1998;20:452-64.

[7]. Elnashai AS. "Advanced inelastic static (pushover) analysis for earthquake applications". Aust J StructEngMech 2001;12(1):51-69.

[8]. CSI. SAP2000 V-14. "Integrated finite element analysis and design of structures basic analysis reference manual". Berkeley (CA, USA): Computers and Structures Inc; 2010.

[9]. IS-456:2000, "Code of practice for plain and reinforced concrete”, code practice fourth revision, Bureau of Indian Standards, New Delhi, July 2000.

[10]. Pauley T. and Priestley, M.J.N. "Seismic Design of Reinforced Concrete and Masonry Buildings". New York; John Wiley and Sons; 1992.

[11]. NeenaPanandikarHede and Dr.K.S.Babunarayan, "Sensitivity of Pushover Curve to Material and Geometric Modelling-An Analytical Investigation”.'Structures 2 (91-97), 2015.Elsevier Science Ltd.

[12]. Mehmet Inel, TjenTjhin and Mark A. Aschheim, “The significance of lateral load pattern in pushover analysis.Fifth national conference on earthquake engineering”, turkey, paper no. AE-009; 2006

[13]. Xuemei Zhao, Yu-Fei Wu,A.Yt. Leung and Heung Fai Lam, "Plastic Hinge Length in Reinforced Concrete Flexural Members"..Procedia Engineering 14 (1266-1274), 2011. Elsevier Science Ltd.

[14]. Mehmet Alpaslan Köro_lu, Musa HakanArslan and MusluKaz_mKörez, "Use of Regression Analysis in Determining the Length of Plastic Hinge in Reinforced Concrete Columns". International Scholarly and Scientific Research \& Innovation 8(4); 2014.

\section{BIOGRAPHIES}

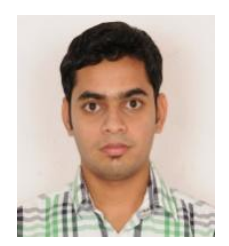

Sripad. D.B, M.Tech Student, Structural Engineering, Manipal Institute of technology, Manipal, Karnataka, India.

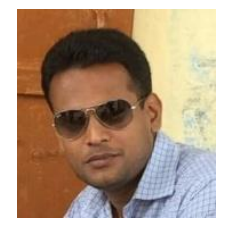

Dr. Poornachandra Pandit, Assistant Professor, Civil Engineering, Manipal Institute of Technology, Manipal, Karnataka, India 